\title{
PENGARUH LAMA PENGGUNAAN MULSA DAN DOSIS PUPUK KANDANG TERHADAP PERTUMBUHAN CABAI (Capsilum Annum) SEBAGAI BAHAN PENYUSUN PETUNJUK PRAKTIKUM BIOLOGI KELAS XII SMA NEGERI 1 BARAT
}

\author{
Zainal Aripin \\ SMAN 1 Barat, Kabupaten Magetan \\ email : zainalaripin0@gmail.com \\ Diterima 7 Januari 2016, Disetujui 21 Maret 2016
}

\begin{abstract}
Learning biology is one area of Natural Sciences (IPA) which is integral with practical activities. The lab activities are very important in understanding science concepts. One material that requires practical learning activities more meaningful so that the material of plant growth and development of class XII Science. It would require new innovation in the development lab manual. This study aims to make research the effect of duration of use and dose of manure mulch on plant growth chili as the building blocks lab manual.This research was conducted using a "Research and Development" (Research and Development). At this stage of research using Grid Design Divided (RPT) which uses two treatments, use of mulch and manure dose use with penggulangan 3 times, while in the Development stage using the results of research into practical instructions were validated by various experts. Based on the results of research and development, we can conclude several things: study the effect of long use of mulch and a dose of manure on the growth of chili can be used as the building blocks of manual lab work with Highlights Growth and Development Plant class XII Science developed in this study expressed very valid, based validation results from two experts namely materials experts and media specialists, with a $88 \%$ value validation.
\end{abstract}

Keywords: mulch, manure, chili growth, lab manual, growth and development of plants.

\section{PENDAHULUAN}

Pembelajaran biologi merupakan salah satu bidang Ilmu Pengetahuan Alam (IPA) yang tidak terpisahkan dengan kegiatan praktikum. Kegiatan praktikum tersebut sangat penting dalam memahami konsep sains. Banyak hal yang menjadi faktor penyebab kegiatan praktikum yang biasa dilaksanakan menjadi kurang bermakna. Salah satunya adalah desain praktikum sebagai petunjuk prosedur pelaksanaan praktikum yang kurang mengarahkan siswa untuk menghubungkan aspek konseptual dengan aktifitas yang dilakukan. Ketidakbermaknaan dalam kegiatan praktikum tersebut menunjukkan perlu dikembangkan sebuah dimensi pengetahuan yang harus terdapat pada desain praktikum untuk membantu siswa dalam membimbing tahapan-tahapan belajarnya serta menghubungkan aspek konseptual dengan objek/peristiwa yang diobservasinya. Dalam pembelajaran Biologi kelas XI khususnya dalam pembahasan pertumbuhan dan perkembangan, praktikum yang digunakan selalu dengan cara mengamati perkecambahan kacang hijau. Hal ini menunjukan bahwa tidak adanya perkembangan terhadap desain penelitian kepada siswa.

Pertumbuhan dan perkembangan tanaman dipengaruhi oleh suhu lebih dari faktor lingkungan lainnya pada saat air 
bukan merupakan faktor pembatas. Sejauh ini, petani tradisonal masih menaman Cabai di tanah yang terbuka. Akibatnya banyak tanaman penggangu yang muncul, serta terjadinya evaporasi tanah pada musim kemarau. Pupuk organik adalah kunci dari pemupukan yang tepat karena pupuk organik, khususnya pupuk kandang mempunyai beberapa keunggulan yaitu dapat memperbaiki struktur fisik, kimia, dan biologi tanah serta memberikan tambahan bahan organik dan mengembalikan hara yang terangkut oleh hasil panen sebelumnya (Suwahyono, 2011).

Pupuk organik adalah kunci dari pemupukan yang tepat karena pupuk organik, khususnya pupuk kandang mempunyai beberapa keunggulan yaitu dapat memperbaiki struktur fisik, kimia, dan biologi tanah serta memberikan tambahan bahan organik dan mengembalikan hara yang terangkut oleh hasil panen sebelumnya (Suwahyono, 2011). Tujuan penelitian adalah: 1) untuk menganalisis pengaruh lama penggunaan mulsa dan dosis pupuk kandang terhadap pertumbuhan cabai (capsilum annum), 2) menyusun panduan praktikum biologi kelas XII SMN 1 Barat Kabupaten Magetan.

\section{METODE PENELITIAN}

Penelitian dilakukan menggunakan pendekatan "Penelitian Pengembangan" (Research and Development). Menurut Sugiyono (2010) penelitian pengembangan adalah metode penelitian yang digunakan untuk menghasilkan produk tertentu dan menguji keefektivan produk tersebut. Penelitian Research and Development ( $\mathrm{R}$ \& D) meliputi tiga tahap, yaitu tahap research, development dan research again. Penelitian yang bersifat analisis kebutuhan digunakan untuk dapat menghasilkan produk tertentu. Analisis kebutuhan ini adalah tahap research. Pada tahap development, dibuat produk yang ingin dikembangkan, sedangkan untuk menguji keefektivan produk tersebut supaya dapat digunakan oleh sasaran, maka diperlukan penelitian (research again) untuk menguji keefektivan produk tersebut.

Petunjuk praktikum yang dikembangkan dinyatakan layak apabila memenuhi kriteria sebagai berikut.

1. Jumlah skor validasi pakar $\geq 81,25 \%$

2. Rata-rata skor tanggapan siswa dan guru $\geq 81,25 \%$

3. Petunjuk praktikum yang dikembangkan dinyatakan efektif apabila:

4. Minimal $90 \%$ siswa memperoleh nilai hasil belajar $\geq 75$

5. Minimal $90 \%$ siswa aktif dalam kegiatan pembelajaran

\section{HASIL DAN PEMBAHASAN}

Penelitian pada tahap research menggunakan Rancangan Petak Terbagi (RPT) yang menggunakan dua perlakuan yaitu penggunaan Mulsa dan dosis penggunaan pupuk kandang dengan penggulangan 3 kali. Pada perlakuan I penggunaan mulsa yaitu tanpa mulsa (M0), penggunakan mulsa sampai 14 hst (hari setelah tanam) (M1), penggunaan mulsa sampai 21 hst (M2). Pada perlakuan II penggunaan dosis pupuk kandang yaitu tanpa pupuk kandang (P0), pupuk dosis 1,5 $\mathrm{kg} / \mathrm{m}$ (P1), Pupuk dosis $/ 2 \mathrm{~kg} / \mathrm{m}$ (P2). Adapun data hasil pengamatan pertumbuhan tinggi tanaman terdapat pada Tabel 1

Berdasarkan data pada Tabel 1 menunjukkan bahwa mulsa dan dosis pupuk kandang memiliki pengaruh terhadap tinggi tanaman. Hal ini menunjukan bahwa mulsa dan dosis pupuk kandang merupakan faktor yang mempengarui pertumbuhan tanaman cabai. Perlakuan M2P1 yaitu penggunaan mulsa 
21 hst dan dosis pupuk kandang $1 \mathrm{~kg} / \mathrm{m}$ tinggi tanaman lebih tinggi dibandingkan perlakuan kontrol yaitu M0P0. Hasil penelitian terhadap rerata pertumbuhan jumlah daun seperti pada Tabel 2.

Tabel 1. Data Rerata Hasil Pengamatan Pertumbuhan Tinggi Tanaman Cabai

\begin{tabular}{cccc}
\multirow{2}{*}{ Perlakuan } & \multicolumn{3}{c}{ Umur Tanaman } \\
\cline { 2 - 4 } & $\mathbf{7}$ hst & $\mathbf{1 4}$ hst & $\mathbf{2 1}$ hst \\
\hline M0P0 & 7 & 12 & 16 \\
M0P1 & 7 & 13 & 17 \\
M0P2 & 6,5 & 12,3 & 15,4 \\
M1P0 & 7,3 & 11,7 & 14,7 \\
M1P1 & 7 & 13,3 & 15 \\
M1P2 & 6,7 & 10,7 & 13,3 \\
M2P0 & 7 & 11,7 & 14 \\
M2P1 & 7,7 & 13 & 16 \\
M2P2 & 6,7 & 12 & 15,7 \\
\hline
\end{tabular}

Tabel 2. Data Rerata Hasil Pengamatan Pertumbuhan Jumlah Daun Tanaman Cabai

\begin{tabular}{cccc}
\hline & \multicolumn{3}{c}{ Umur Tanaman } \\
\cline { 2 - 4 } Perlakuan & $\mathbf{7}$ hst & $\mathbf{1 4}$ hst & $\mathbf{2 1}$ hst \\
\cline { 2 - 4 } M0P0 & 12 & 27 & 37 \\
M0P1 & 17 & 28 & 41 \\
M0P2 & 12 & 17 & 26 \\
M1P0 & 16 & 23 & 30 \\
M1P1 & 17 & 27 & 28 \\
M1P2 & 17 & 28 & 40 \\
M2P0 & 16 & 23 & 32 \\
M2P1 & 18 & 29 & 43 \\
M2P2 & 17 & 23 & 30 \\
\hline
\end{tabular}

Berdasarkan Tabel 2 menunjukan bahwa perlakuan M2P1 mempunyai jumlah daun lebih banyak dibandingkan perlakuan kontrol yaitu M0P0, hal ini sesuai dengan penelitian Rachmiati dan Salim (2003) bahwa dengan menggunakan mulsa dengan interval waktu 21 hst akan mengalami pertambahan jumlah daun yang lebih banyak karena dengan penggunaan mulsa, akan mempercepat proses transpirasi. Hasil penelitian berdasarkan data yang telah diperloeh dapat dijadikan sebagai salah satu bahan penyusun buku petunjuk praktikum pembahasan pertumbuhan dan perkembangan bagi siswa.

\section{Pengembangan Hasil Penelitian sebagai Bahan Penyusun Petunjuk Praktikum}

Pengembangan atau Development, hal yang dikembangkan dari hasil penelitian ini yaitu mengembangkan hasil penelitian menjadi bahan pengembangan petunjuk praktikum. Bahan petunjuk praktikum yang dikembangkan yaitu hasil penelitian pengaruh lama penggunaan mulsa dan dosis pupuk kandang terhadap pertumbuhan tanaman cabai menjadi salah satu petunjuk praktikum pada materi perkembangan dan pertumbuhan tumbuhan kelas XII IPA SMA.

\section{Validasi Kelayakan Petunjuk Praktikum}

Pengembangan petunjuk praktikum divalidasi 2 orang pakar yaitu satu guru yang berkompeten pada materi pertumbuhan dan perkembnagan dan satu guru Biologi yang berkompeten dalam bidang media pembelajaran. Validasi petunjuk praktikum menggunakan acuan uji kelayakan petunjuk praktikum yang telah disediakan dalam bentuk angket (Tabel 3) yang meliputi komponen kebenaran konsep, kejelasan kalimat dan tingkat keterbacaan, tingkat keterlaksanaan kegiatan praktikum, dan evaluasi pembelajaran. Masing-masing komponen tersebut dijabarkan dalam beberapa butir

Tabel 3. Hasil validasi produk oleh ahli (pakar) 
Aripin

\begin{tabular}{llcc}
\hline No & \multicolumn{1}{c}{ Jenis Pernyataan } & Guru Biologi & $\begin{array}{c}\text { Dosen ahli } \\
\text { materi }\end{array}$ \\
\hline $\mathbf{1}$ & Kebenaran konsep & $75 \%$ & $100 \%$ \\
$\mathbf{2}$ & Kejelasan kalimat dan keterbacaan & $75 \%$ & $75 \%$ \\
$\mathbf{3}$ & Tingkat keterlaksaanan praktikum & $75 \%$ & $95 \%$ \\
$\mathbf{4}$ & Merangsang keinggintahuan peserta didik & $75 \%$ & $95 \%$ \\
$\mathbf{5}$ & Evaluasi Pembelajaran & $75 \%$ & $75 \%$ \\
& rata - rata & $75 \%$ & $88 \%$ \\
\hline
\end{tabular}

Ahli materi maupun ahli media pembelajaran memberikan hasil validasi dengan kriteria "baik" demikian juga penilaian dari dosen juga "baik". Pakar memvalidasi dengan nilai sebesar $88 \%$ yang berkriteria "sangat layak". Hasil tersebut sudah memenuhi kriteria kelayakan petunjuk praktikum, dengan jumlah skor validasi pakar $<81,25 \%$, sehingga petunjuk praktikum dinyatakan layak sebagai petunjuk praktikum yang dapat digunakan siswa dalam pembelajaran. Petunjuk praktikum merupakan media tertulis yang berguna sebagai penyalur informasi kepada siswa, sebagaimana Yamin (2007) yang menyatakan bahwa media adalah suatu perangkat yang menyalurkan informasi dari sumber ke penerima informasi.

\section{KESIMPULAN DAN SARAN}

\section{Simpulan}

Berdasarkan hasil penelitian dan pengembangan, dapat disimpulkan beberapa hal yaitu penelitian pengaruh lama penggunaan mulsa dan dosis pupuk kandang terhadap pertumbuhan cabai dapat dijadikan sebagai bahan penyusun petunjuk praktikum dengan pokok bahasan pertumbuhan dan perkembangan tumbuhan kelas XII IPA yang dikembangkan dalam penelitian ini dinyatakan sangat valid, berdasarkan hasil validasi dari 2 orang ahliyaitu ahli materi dan ahli media, dengan nilai validasi $88 \%$.

\section{Saran}

Hasil penelitian kegiatan praktikum dapat dikembangkan sebagai bagian dalam penilaian psikomotorik siswa, demikian pula dapat dikembangkan dalam materi lain. Kegiatan praktikum juga dapat meningkatkan pembelajaran kontekstual bagi siswa.

\section{DAFTAR PUSTAKA}

Hermawan dkk. (2013). Pengaruh Lama Penggunaan Mulsa Dan Pupuk Kandang Pada Pertumbuhan Dan Hasil Tanaman Jagung (Zea Mays L.) Varietas Potre Koneng. Jurnal Produksi Tanaman Vol. 1 No. 4. Universitas Brawijaya . Malang

Meyhandoko, Adityas. (2013). Skripsi. Pengembangan Petunjuk Praktikum Kontekstual Dengan Pemanfaatan Kondisi Lingkungan Lokal Dalam Pembelajaran Pencemaran Lingkungan di SMAN 2 Rembang. UNNES. Semarang.

Rachmiati, Y. Salim, A, A. (2003). Pengaruh Penggunaan Berbagai Bahan Mulsa dan Interval Pemberian Air Terhadap Kadar Air Tanah dan Pertumbuhan Tanaman Teh Belum Menghasilkan Klon GMB 7 Pada Inseptisols. Jurnal Prosiding Simposium Teh Nasional. 236 - 241.

Sawitri S. (2008). Model Pengembangan Buku Petunjuk Praktek Mata Kuliah 
Draping. Jurnal Penelitian Pendidikan. Vol 24 no 1 hal 23-24

Sitompul, S.M. dan B. Guritno. (1995). Analisis Pertumbuhan Tanaman. Gadjah Mada University Press. Yogyakarta.

Sugiyono. (2011). Metode Penelitian Kuantitatif Kualitatif dan $R \& D$. Bandung : Alfabeta.

Sumarni, N., A. Hidayat, dan E. Sumiyati. 2006. Pengaruh Tanaman Penutup Tanah dan Mulsa Organik terhadap Produksi Cabai dan Erosi Tanah. Balai Penelitian Tanaman Sayuran. Lembang. J.Hort. 16 (3) : 197-201

Suwahyono. (2011). Petunjuk Praktis Penggunaan Pupuk Organik Secara Efektif \& Efisien. Penebar Swadaya. Bogor

Widiastuti, E. (2005). Pengaruh Pemberian Mulsa Plastik Hitam Perak dan Pemupukan Nitrogen terhadap Pertumbuhan dan Produksi Tanaman Cabai Varietas Lado. Skripsi, Universitas Lampung. Bandar Lampung.

Yamin HM. (2007). Desain Pembelajaran Berbasis Tingkat Satuan Pendidikan. Jakarta: Gaung Persada Perss. 